この一方で, 電子技術の発達が多自由度機構を普及させ。 マニピュレータに見られるような、歯車やチェーンなど を沢山組又合わせた相当複雑な機構を増加させているの は興味あることである。

このような複雑な機構の設計に際し、動力源の分散か 集中か，伝澾要素に何を選定しどのように組み合わせる べきか，など多くの問題を生じる。しかし，こ机吏での 機構の学は、こ机らの問題に合理的な解老与克る力! まりないようである、今後の機構の学は、このよらなシ ンセシスにも強い支援が与员ら机るように構築さ机るべ きであろう。

\section{3. 今後の動 向}

最近は機構す, 出力䛊差をつィードバック系で補正す る制御系の一環として扱わ机ることが多くなった。これ は，これまでの機構の精度という概念に根本的な見直し を迫るものとい党よう。検出の分解能とアクチュエータ の能力があれば，寸法䛊差や摩耗䛊差を，少なくとも原 理的には，自動補正できるからである。

子ち万ん，機械的精度は依然重要である。制御方向以 外のすべての座標方向は機械的に拘束され，それらが高 精度でなければ制御方向の精度も無意味になるからであ る。また，現在の制御技術では補正困難な多くの要因が あり, これらの対策として高精度, 高剛性, 低摩擦の機 構を必要とするからである。

制御技術は，優れた機構の性能をさらに高めるために 利用すべきものといらのが現在の妥当な理解であろら. しかし、今後の機素, メカニズムの評価は, 制御技術と の総合の中で考光ねばならないようになっていくことは 確実である。

(なかがわ・双つ招 昭和 58 年 9 月 7 日受付)

\section{自 動 組 立}

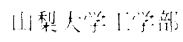

牧野洋

\section{1. 自動組立の歩み}

日本に书计る自動組立の歴史”はたかだか20伴ぐら

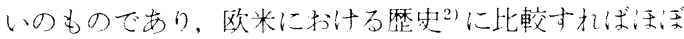
15 年の遅机があると考光ら机た。しかしながら。この 20

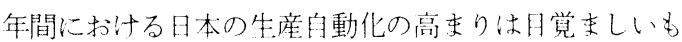
のがあり、今では欧米之肩を並べ，あるいは特定の分野 に㧅ては欧米老抜く之考兄ら机るに至っている。

とくにここ数年間のフレキシブル生産システム (FMS)の導入においては，日本は質量ともに世界の トップを走っており，組立程においても，組立作業に 適したロボットの開発を軸にして、フレキシブルな自動 組立ラインが続々と誕生する勢いにある。

最近 10 年間の自動組立の流れてを端的に表現するなら ば，乙れは専用機による単品種大量生産から沉用機によ る多品種少量生産への怒涛のような流れである。そうし て、コンピュータの応用が深く静かに浸透して来たこと が感ぜられる。

\section{2. 自動組立技術の発展}

自動組立に関する技術はいまだ「江学」と呼べる程に は体系化されていない，しかし，少なくとも専用機技術 に関する限り，その標準的な手法は確立されたように見 える。东た，汎用機技術についても，専用機技術をべー スにしながらそのトにシステム的な思考を加えて，幾つ かの手法が実験的にトライされ，そしてそのうちの幾つ

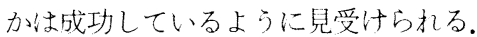

自動組立技術は一種の総合技術であって，その基盤と なる工学は幅広い，組立法というンフトウェアと，自動 組立機械という八ードウェアが一体になって初めて自動 組立が可能になるのである。したがって，その基盤とな る土学もンフトに関するものと八ードに関するものの両 方が要求される。

\section{3. 自動組立の 3 要素}

組付计 (Assembly)，移送 (Transfer)。供給 (Feed. ing)の 3 者を自動組立の 3 要素々呼んでいる。こ机らか

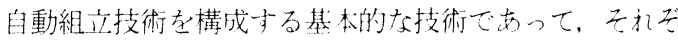
机に㧈计る開発が自動組立システム全体の開発を押し進 
めてきた。たとえば，組付けに打いててなムを利用した 高速のつ来及装人 (Pick-and-place) 機構の開発, 詰李 りのないはめあい老叮能にするコンフライアンス機構の 開発、移送に扔いててはカム式インデックスユニットの開 発,フリーフローコンベアの開発, 供給に执いては振動 ボウルホッパフィーダの開発, パターン認識を応用した 部品の位置・姿勢判別装置の開発などである。これらの うちのあるものはフィックスドオートメーションに，あ るものはフレキシブルオートメーションに向いている が，双方に対して共通に用いら机る技術もあり，さらに 一層の研究開発が望李机るところである。

\section{4. 講演発表内容の分析}

精機学会自動組立専門委員会は 1968 年 (昭和 43 年) の 12 月に設立され，以来今日 $(83$ 年 8 月現在)までの間 に52 回の研究発表会と 60 回の研究例会を開催してき た。この専門委員会が設立された時期は日本においてて自 動組立の導入が始まった時期に当たって抢り，それ以後 今日に至るまでの専門委員会に打ける講演発表の内容は その本日本に抢计る自動組立の進展を反映していると 考克られる.

図1一図3はこの間にお汁る合計 340 件の講演発表の 内容を次の 9 つのテーマに分類して集計したものであ る.

（1）計画一一組立自動化の計画, 導入に当たっての考 之方, 採算性, 評価, 問題点, 自動組立機㑘の稼動 率，用語，シンボル記号，製品設計など.

（2）実例一一自動組立機械の実例, 各社の機械の紹介, 自動配線機械，電子部品製造機械，諸外国の現状， 海外の動向報告など.

（3）システム—自動組立システム，多種少量生産の ための自動組立など。

（4）ロボット—組立用口ボットの開発, 応用例, サ一 ボエレメント，フィン゙ガなど.

（5）制御一ーシーケンス制御，油空厓制御回路，セン サ，娭査機械など。

（6）組付け一一結合, 接着, 溶着, 权じ締め, 装入, はめあい，組立法など。

（7）機構一一移送機構，標準機械，フリーサイクル方 式，カム、インデックス，つま久装入機構，油空圧 機器, 各種機械のメカニズムなど.

（8）供給一一部品自動供給法, 整列, ペーッハンドリ ング, ホッパフィーダ, 振動フィーダ, 静電気除去, 工場内物流, 部品形状解析, 形状娭出, 視覚など.

(9) 関連技術一 $-\mathrm{NC}, \mathrm{CAD}$ ，機械加工に打沙る自動 化など.

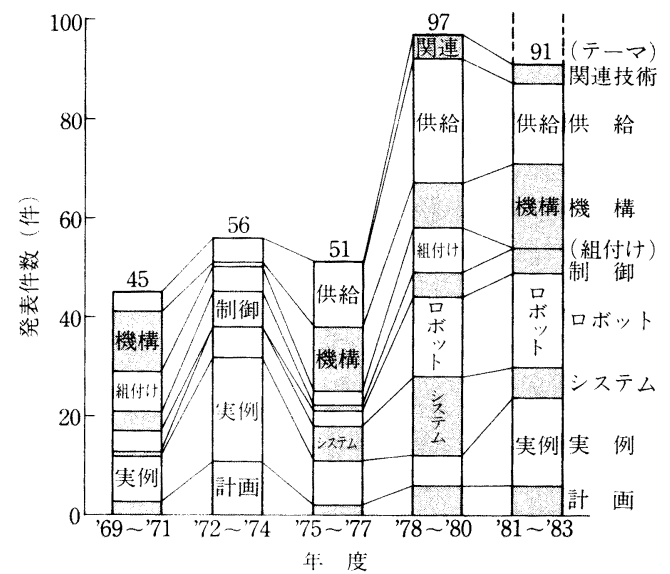

図 1 自動組立専門委員会におけるテーマ別発表件数

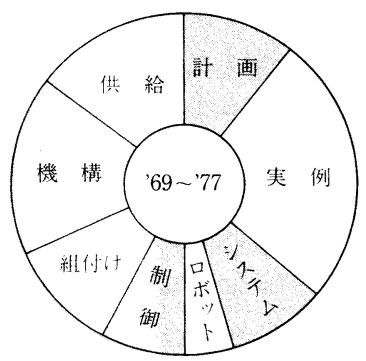

図21969 77の9年間に抢ける発表テーマの割合

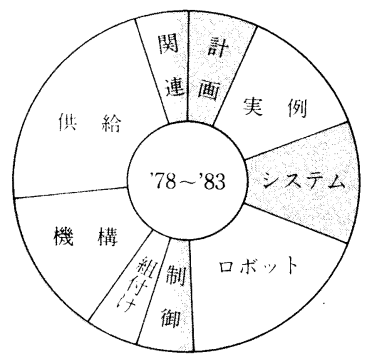

图３1978８306 件間に扮忛る発表テーマの割合

図 1 は以上の 9 テーマに関する発表件数を 3 年ごとに 区切って示したものであるが，当初は自動組立の計画や 導入事例に関するものが多く，自動組立とはどういうも のかといら啓蒙的な発表が大半を占めた。

72 年ころからンステムに関する議論が盛んになり, と くに多種少量生産の任動組立を可能にする方式について 繰り返し討論が行われた。ややが，80 年ころからこれを 解決する一つの手段としての組立用ロボットが出現し, その基本的な機構や，導入実例などが紹介され，供給方 法に関しても視賞装置による部品判別などが盛んに発表 された、また，最近では口ボットの要素や周辺機器の人 カニズムに関しても議論が活発に行わ机ている.

図 2 抢よび図 3 はこの 15 年間を始めの 9 年間と後の 
78

6 年間に分けて発表題目の割合を示したものであって, 後者ではロボットに関する発表の割合が増えてきたこと が分かる。

\section{5. 今後の問 題}

自動組立技術はまだ開発途上にあり, 新しい手法や機 器が次々に生まれている状涗にある。 かなりの進歩を遂 げだ部品供給法にしてもまだ完全なものとは言えず，と くにフレキシビリティのある供給法はこれからの問題で ある。

$\mathrm{NC}$ 組立機械や組立用口ボットを主体にした自動組立 ラインやアセンブリセンタシステムは今後ますます増克 ることと思わ机るが，これに関連していろいろな意味で の制御が問題になる。また異なるメ一力間の機器の互換 性が必要となり, ロボット言語の統一化, ハンドや工具 の標準化が緊急の課題となっている.

また，従来自動組立は小物部品に対して適用されてき たが，大型の製品をどのように自動で組立てるかは未解 決の問題であり, 大型ロボットの開発と合わせて研究さ れるべき問題であると思わ机る。

(まきの・ひろし 昭和 58 年 9 月 16 日受付)

\section{文献}

1) 谷口紀男, 牧野 洋: 日本に㧍汁る自動組立の歴史と現 状, 精密機械, 39，4 1973) 342 .

2）牧野洋：欧米に求计る自動組立の歴史と現状，精密機 械, 38，3（1972）241.

\section{計測の体系化と精密工学}

計荲研究所

矢野宏

計測分野の体系化に関して，この 10 年:の進展，近々の 予想, 問題点を書くといらのが課題である。どうしたも のかと途方に暮れている。体系化といらことなので，を れに関係のありそうな資料にあたることから始めた。东 ず，精密工学と計測といら言葉から，真先にイメージき れるのが精密測定といらことである。これについては， 古典ともい学る著書に, 渡过らによる「精密機械の基礎 がある1．これは測定を基礎測定，諸量測定，ブロック ゲージ，測定及び製作誤差論に分けて，それぞれの測定 項目について体系的に述べられている。以後の精密測定 にかかわると思われる教科書は，棌とんどこの本の考兄 方を踏襲している，これを精密工学科系の計測の体系化 と寸れば，計測工学あるいは応用物理学の方面で，真島 らによる計測工学に関するいくつかの著書がある213!。こ の二つの系統を比較して見ると少々割り切って言兄ばー。 方が機械的要素を中心とした測定, 他方が物理実験的要 素を中心とした測定になると思う。しかし，いずれにし ても，具体的な量を対象とした測定である。実際に測定 を行うとなると，これらのことは不可欠の知識となるか ら，これからも必要なものであるに違いない。

これらの著書の年代より少し新しくなると，計測とい らことがかなり前面に出て来る。特定の量を対象とする のでなく, 機械量, 力学量, 電気量といった形で, 量を 情報として扱らといら方向と言光ようか。たと光ば，寺 尾の「測定論 $\rfloor^{4}$, 谷口「計測通論」5)などで, アナグロ・ ディジタル変換,データ伝送といった形で扱わ机ている.

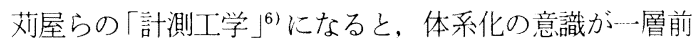
面に押し出されている，又，新しい方向として，実験計 画法, 誤差論などを詳しく取り入れているのも特徵之言 光よらが、ささらに，計測管理といら言葉が使われると， 制御，自動化，工程管理なども扱わ机ている ${ }^{8)}$. ただし， 精機学会だけに限って見ると、こうした全体的な体系化 に対しては，部分的といら感じを否めない．

ところで 40 周年の時の学会誌を調べてみると、招 らく 1975 年 1 月号「転回期にある精密!学の課題」がこ れに相当すると思われるが，奈良により表面粗さ分野を 中心とした課題が述べられている9!. 精機学会としての 特色が出ている代わりに，計測全体の体系化とは言兄な 